\title{
Prevalence of Nonsmoking Area at Ternate City in 2019
}

\author{
Imam Rifial Arazi $^{1^{*}}$, Suharto ${ }^{2}$, Suryani Mansyur ${ }^{1}$ \\ ${ }^{I}$ University of Muhammadiyah Maluku Utara, Faculty of public Health, Jalan KH Ahmad Dahlan 100 Kelurahan Sasa, \\ Kota Ternate Selatan, 97719, Ternate city, North Maluku, Indonesia \\ ${ }^{2}$ Port health office of Manado city, North Sulawesi, Indonesia \\ * Corresponding Author. Email:_imamrifial97@gmail.com
}

\begin{abstract}
Non Smoking area (NSA / KTR) is a room or area that is declared prohibited for smoking or producing, selling, advertising, and / or promoting tobacco products. Cigarettes can have many negative impacts on general health, such as cancer of the mouth, pancreas, bladder, blood (leukemia), and lung cancer and diseases heart. No Smoking Area is regulated in local regulation No. 4 in 2014 which requires schools, offices and health facilities to enforce these local regulations in their environment. This study aimed to determine the Prevalence of Schools, Health Facilities and Offices that have implemented the Smoke-free area policy at Ternate City in 2019. This type of research is quantitative research, using descriptive analytical methods. By using a total sampling of 148 observations consisting of 88 schools $(59.5 \%), 53$ offices $(35.8 \%)$ and $7(4,8 \%)$ health facilities. The results showed that there were $12(8.1 \%)$ observation sites which were suitable for the implementation of non-smoking areas and there were 136 (91.9\%) observation sites which were not suitable for the implementation of the smoke free area. The low level of non-smoking area implementation on the city of Ternate needs to get the attention of policy makers so It is suggested that the importance of the socialization about regional regulation on non-smoking areas and commitment of policy implementers and enforcement of sanctions that can provide a deterrent effect for those who do not impose no smoking area, so that it can reduce the negative impact on public health.
\end{abstract}

Keywords: nonsmoking area, cigarette, local regulation, implementation of the smoke-free area

\section{INTRODUCTION}

The number of smokers around the world now reaches 1.2 billion people and 800 million of them are in developing countries. According to WHO data, Indonesia is the third country with the largest number of smokers in the world after China and India. According to The Tobacco Atlas 3rd edition 2009, related to the percentage of world population who consume tobacco found $57 \%$ in the population of Asia and Australia, 14\% in the population of Eastern Europe and the Soviet Union, $12 \%$ of the American population, $9 \%$ of the population of Western Europe, and $8 \%$ of the population of the Middle East and Africa. Meanwhile ASEAN spread in Indonesia 46.16\%, Philippines 16.62\%, Vietnam 14.11\%, Myanmar $8.73 \%$, Thailand $7.74 \%$, Malaysia 2.90\%, Cambodia $2.07 \%$, Laos $1.23 \%$, Singapore $0.39 \%$ and Brunei $0.04 \%{ }^{1}$

Based on data from the National Statistics Agency in 2016 about the percentage of smoking in the population aged $\geq 15$ years old by province in 2015-2016, North Maluku Province ranks eleventh and the first position is Lampung province with a smoking presentation in 2015 of $34,12 \%$ and in 2016 as much as $33.39 \%$ and for North Maluku province with a smoking presentation in 2015 as much as $31.14 \%$ and in 2016 as much as $30.23 \%$ and the last position was in the Province of Bali with a smoking presentation in 2015 as much as $22.96 \%$ and in 2016 as much as $21.62 \%{ }^{2}$
Cigarette consumption in Ternate is also still very high, seen from year to year, always increasing according to BPS (Statistics Indonesia) data, based on the percentage of average expenditure per capita per month according to food groups in Ternate from 2015 to 2017 from these data levels consumption of cigarettes, tobacco, and betel continues to increase every year seen from 2015 the amount of expenditure issued per month per capita is Rp. 67,107 and in 2016 it increased by Rp.82,167 per capita and in 2017 it continued to increase sharply as much as Rp. 110,663 per capita, this is a problem for the city to be able to reduce or even eliminate the consumption of cigarettes in Ternate, one of which is by implementing a good and appropriate No Smoking Area in the layers of society in Ternate. ${ }^{345}$

The purpose of this study is to determine the Prevalence of Schools, Health Facilities and Offices that have implemented the No Smoking Area in Ternate City in 2019.

\section{METHOD}

This research was conducted in July - August 2019 with the research location in Ternate city. This type of research is quantitative research, using non-analytic descriptive methods. ${ }^{6}$ This research is a continuation of mini survey activities conducted by epidemiology students who used a sample of 26 schools, 6 health facilities and 10 offices, $^{7}$ and 
the remaining sample of 148 samples and made as a total sampling in this study. So that the population in this study are all schools, health facilities (hospitals and health centers), and government offices in the city of Ternate. The sample size in this study were 148 observation places consisting of 88 schools, 55 elementary schools, 18 junior high schools and 15 high schools, 7 health facilities and 53 offices from 190 populations in Ternate.

\section{RESULTS AND DISCUSSION}

The implementation status of Non-Smoking Areas (KTR) in Ternate City were $12(8.1 \%)$ observation sites that were suitable for their application and as many as $136(91.9 \%)$ observation sites that did not meet KTR requirements (table 1). Indicators of the application of KTR in the City of Ternate School Order can be seen from the indicator of the unavailability of places / rooms / locations for smoking, which is $78(52.6 \%), 38$ smoking bans $(25.5 \%)$ were found, there was no smell of cigarette smoke in schools $62(41.6 \%)$, No ashtrays / matches found 62 (41.6\%), no cigarette butts found $24(16.3 \%)$, no people smoking was found $(65$ (44.2\%), no items were found related to smoking $84(56.5 \%)$ and 85 people $(56.5 \%)$ were not found selling cigarettes in the school environment (table 2)

Health facilities observed were $7(4.8 \%)$ which did not provide a smoking place / room, found no smoking sign 6 (4.1\%), did not smell smoke 7 (4.8\%), no ashtray / lighter found $7(4.8 \%)$, no cigarette butts found in only 5 health facilities $(3.4 \%)$, no smoking was found namely in 6 health facilities $(4.1 \%)$, no items related to cigarettes and people were found. who sell cigarettes in the environment at 7 health facilities $(4.8 \%)$. (Table 3 )

In city government office agencies, indicators that meet the requirements for the application of a non-smoking area are 25 offices (17\%) available for smoking, 34 offices $(23 \%)$ that put up a no smoking sign, no smell of smoke in 24 offices $(16 \%)$, no ashtrays / matches were found in 21 offices $(14 \%)$, no cigarette butts were found in 16 offices $(11 \%)$, no smoking was found in 28 offices (19\%), No items were blessed with cigarettes as many as 48 offices (32\%) and no cigarette advertisements found in the office environment as many as 52 offices $(35 \%)$. (Table 4$)$

Table 1. Analysis Results that required the implementation of a Non-Smoking Area

\begin{tabular}{lcc}
\hline \multicolumn{1}{c}{ Indicator } & Frequency & Percentage (\%) \\
\hline required non Smoking Area & 12 & 8.1 \\
Not Required the non smoking Area & 136 & 91.9 \\
\hline Total & 148 & 100 \\
\hline
\end{tabular}

Table 2. Analysis Results of Non-Smoking Area Indicators in Schools

\begin{tabular}{lccc}
\hline Variabel / indicators & Category & Frequency & Percentages $(\%)$ \\
\hline Smoking area & Not avalable & 78 & 52,6 \\
No smoking signs & found & 38 & 25,5 \\
Cigarette smoke & Not odor & 62 & 41,6 \\
Asthtray / Lighter & Not found & 62 & 41,6 \\
Cigarette butt & Not found & 24 & 16,3 \\
People smoke & Not found & 65 & 44,2 \\
Goods related to cigarctte & Not found & 84 & 56,5 \\
People sell cigarettes in the & Not found & 85 & 56,5 \\
Invorenment & & & \\
\hline
\end{tabular}

Table 3. Analysis Results of Non-Smoking Area Indicators in Health Facilities

\begin{tabular}{|c|c|c|c|}
\hline$\overline{\text { Variabel / indicators }}$ & Category & Frequency & $\begin{array}{l}\text { Percentages } \\
(\%)\end{array}$ \\
\hline Smoking area & Not available & 7 & \\
\hline No smoking signs & found & 6 & 4,1 \\
\hline Cigarete smoke & Not odor & 7 & 4,8 \\
\hline Asthtray / Lighter & Not found & 7 & 4,8 \\
\hline Cigarette butt & Not found & 5 & 3.4 \\
\hline People smoke & Not found & 6 & 4,1 \\
\hline Goods related to cigarette & Not found & 7 & 4.8 \\
\hline $\begin{array}{l}\text { People sell cigaretes in the } \\
\text { Lnvorenment }\end{array}$ & Not found & 7 & 4.8 \\
\hline
\end{tabular}

Table 4. Analysis Results of Non-Smoking Area Indicators in the office

\begin{tabular}{lccc}
\hline Variabel/ indicators & Cattegory & Frequency & $\begin{array}{c}\text { Percentages } \\
\left(\left(_{0}\right)\right.\end{array}$ \\
\hline Smoking area & available & 25 & 17 \\
No smoking signs & found & 34 & 23 \\
Cigarette smoke & Not odor & 24 & 16 \\
Asthtray / Lighter & Not found & 21 & 14 \\
Cigarette butt & Not found & 16 & 11 \\
People smoke & Not found & 28 & 19 \\
Goods related to cigarette & Not found & 48 & 32 \\
$\begin{array}{l}\text { People sell cigarettes in the } \\
\text { Invorenment }\end{array}$ & Not found & 52 & 35 \\
\hline
\end{tabular}

\section{DISCUSSION}

1. Status of Implementation of Non Smoking Area

Non Smoking Area (KTR) is a room or area that is prohibited for smoking or producing, selling, advertising, and/or promoting tobacco products. Government through Law No. 36 of 2009 concerning health and PP No. 109 of 2012 concerning Safeguarding Materials Containing Addictive Substances in the Form of Tobacco Products for Health also requires local governments to establish KTR in their respective Regional Regulations or other regional legislation. ${ }^{8}$

For Ternate City Regional Regulation (PERDA) regulating non-smoking areas is included in Regional Regulation number 4 of 2014 concerning the Public Order of the Twelfth Section on Smoking Regulations Article 28. ${ }^{9}$ The implementation status of KTR (No-Smoking Area) is assessed from the eight KTR assessment indicators in Offices, Schools (elementary, junior high, high school) and health facilities (public health centres and hospitals) that is, the presence and absence of smoking areas provided, the presence of no smoking signs, no smell of cigarette smoke, no matches or ashtrays, no no cigarette butts, no smoking people, no items or things related to cigarettes such as ashtrays, tablecloths, paper towels and so on, and no one sells cigarettes around the office, school (elementary, middle, high school) and Health Facilities (public health centres and Hospitals). Based on the research results obtained that are in line with the implementation status of KTR (No Smoking 
Area), there are $12(8.1 \%)$ suitable observation places and $136(91.9 \%)$ observation sites that are not appropriate, for those that are in accordance with KTR implementation status consists of 5 elementary schools (3.4\%), Senior high school 4 (2.7\%), Puskesmas $1(0.7 \%)$, and Hospital 2 (1.4\%), and for those who did not reach the KTR implementation status consisted of elementary schools as many as $50(34 \%)$, junior high schools have $18(12 \%)$, high schools have $11(7.4 \%)$, there are 1 health centers $(0.7 \%)$, hospitals have $3(2 \%)$ and offices have $53(36 \%))$.

From the results of research conducted by the Office of Environmental Health Engineering and Disease Control Class 1 Manado (2018) in Central Halmahera District conducted at the school shows that according to the implementation of KTR there is 1 observation site (6.7\%) and that is not according to KTR implementation there were 14 observation places $(93.3 \%)$, then out of the 4 offices that became observations all of them did not reach the requirements for implementing a non-smoking area. ${ }^{10}$

\section{Place / Room / Location for Smoking}

Based on indicators issued by the Ministry of Health in 2011 for the Smoking Area in the office should be provided for the smokers while the Smoking Area in schools and health facilities should not have to be provided for the smokers. ${ }^{11}$ Based on the results of the study show that, the number of schools that have the Smoking Area is based on indicators that there is no place for smoking $78(52.6 \%)$ and they have not meet the indicator $10(9 \%)$ for health facilities they have reached the indicator, and for offices that have reached 25 $(17 \%)$ places of observation and have not reached the indicator $28(19 \%)$.

From the results of the study, there are those who have smoking places / rooms / locations, there are 35 places of observation and those who do not have as many as 113 places of observation, for those who have smoking places, namely the Office as many as $25(17 \%)$, junior high schools are 4 $(3 \%)$, then elementary and high school there are $3(2 \%)$, then for those who do not have the Smoking Area is 28 Offices $(19 \%)$, there are $52(35 \%)$ elementary schools, 14 (9.5\%) junior high schools, $12(8.1 \%)$ high schools.

For offices that have met the requirements for implementing a non-smoking area based on indicators of having a place / room / location for smoking, there are 25 observation places including (Social Service, DPRD, PLN, Food Security Service, RRI, Central Statistics Agency, Port Health Office, Office UKM and Cooperatives, Inspectorate, Religious Courts, BKAD Service, Dandim 1501, Tax Management Agency, Agricultural Quarantine Office, Public Prosecutor's Office, Women's Empowerment Office, KPKNL, Manpower Office, Korpri Secretary, Regional Secretariat Section, Regional Secretariat and Setda Protocol, BMKG, Baabullah UPB Services section and Operations section), which can be an example for other offices to hold a place / room / location for smokers so that they do not smoke in the working area. The availability of a smoking area is provided by a special workspace for employees who are addicted to smoking or made into a room for employees who smoke. ${ }^{12}$

\section{No-Smoking Signs}

A no-smoking sign is a component of the assessment indicator requirements in the application of non-smoking areas which must be held and applied in offices, schools and health facilities and to prevent if there are smokers who want to smoke in areas without smoking according to the Ministry of Health year 2011. Based on the results of the study showed that, the number of observation sites that met the indicator requirements already had a smoking ban sign from 148 observation places namely 78 (49\%), namely in the Office as many as 34 observation places (49\%), elementary schools there are $21(14 \%))$, There were 7 (4.7) junior high schools, $10(6.5 \%)$ high schools, $1(0.7 \%)$ health center and 5 out of $5(3.4 \%)$ hospital samples were fulfilled. while those who did not meet there were $70(47.3 \%)$ places of observation, namely in the Office of 19 places of observation (13\%), elementary schools there are 34 (23\%), junior high schools there are 11 (7.4), high schools there are $5(3.4) \%)$, There is 1 public health centre $(0.7 \%)$.

From the results of the study no smoking signs were obtained and seen many stickers that were posted on the walls, on the glass, on poles and there were also some banners that were installed directly in the observation yard, for offices and health facilities were mostly found in the office space while being used for many schools can be found in offices, school yards and study rooms. In other areas, the application of nosmoking zones in the Metro City area in the City Planning Agency and the environment has no constraints, the delivery of information or instructions No-smoking areas are installed in a number of places such as the main gate of the Metro city health service, parks, parking lots, lobbies, work spaces, mosque / musholla, meeting rooms, canteens and places that are easily read by employees or guests who come to the City Planning Office and Metro City Environment. ${ }^{12}$

\section{Smell of Cigarette Smoke}

According to the Ministry of Health Regulation of 2011 concerning guidelines for non-smoking areas, the smell of cigarette smoke is a component of the requirements for assessment indicators in the application of non-smoking areas in offices, schools and health facilities. Based on the results of the study showed that, the number of observation spots that met the indicator requirements did not smell of cigarette smoke from 148 observation places that were 93 $(63 \%)$, namely in the Office of 24 observation places $(16 \%)$, elementary schools there were $36(24 \%)$, There were 14 junior high schools $(9.5), 12(8.1 \%)$ high schools, and from $2(1.4 \%)$ public health centres and $5(3.4 \%)$ hospitals that were all observed to be eligible. while there were $55(37 \%)$ observations not yet fulfilled, namely 29 offices in the Office $(20 \%), 19(13 \%)$ in elementary schools, 4 (3) in junior high schools, $3(2 \%)$ in high schools. From the results of the study the smell of smoke for the office much in get in the office space while for the school many in the office room and school yard.

\section{Ashtrays and / Matchsticks were Found}

Based on the 2011 Ministry of Health Regulation on nonsmoking area guidelines, it was found that ashtrays and / matches were a component of the requirements for 
assessment indicators in the application of non-smoking areas in offices, schools and health facilities.

Based on the results of the study showed that, the number of observation spots that met the indicator requirements were not found ashtrays / matches from 148 observation places, namely $90(61 \%)$, namely in the Office of 21 observation places $(14 \%)$, elementary schools there were $36(24 \%)$, There were 14 (4.7) junior high schools, 12 (8.1\%) high schools, and from 2 (1.4\%) Puskesmas and $5(3.4 \%)$ hospitals that were all observed to be eligible. while $58(39 \%)$ of those who did not meet the observations were 32 offices $(22 \%)$ in the office, $19(13 \%)$ in elementary schools, $4(3 \%)$ in junior high schools, $3(2 \%)$ in high schools. From the results of the study found an ashtray and / match for the office there is a can outside the place to smoke and there is at the same time found in the smoking area provided and there is also found outside the smoking area provided there is found which is found which deliberately saved for guests if there is smoking, for the school many schools get in the office.

\section{Found Cigarette Butts}

Based on the 2011 Ministry of Health Regulation on nonsmoking area guidelines, it was found that cigarette butts are a component of the indicator requirements for assessing the implementation of no-smoking areas in offices, schools and health facilities. Based on the results of the study showed that, the number of observation places that met the indicator requirements was not found cigarette butts from 148 observation places that were $45(30 \%)$, namely in the Office as many as 16 places of observation $(11 \%)$, elementary schools there were $12(24 \%)$, SMP there were $6(4.1)$, high schools there were $6(4.1 \%)$, and out of $2(1.4 \%)$ all observed health centers were eligible, there were $3(2 \%)$ hospitals while those that did not meet were 103 observation spots namely in the Office as many as 37 places of observation $(25 \%)$, elementary schools there are $43(29 \%)$, junior high schools have $12(8.1 \%)$, high schools have $9(6.1 \%)$ and hospitals have $2(1.4 \%)$. From the results of the study found cigarette butts for the office, school and health facilities are mostly found in the observation yard, for the office to dispose of cigarette butts are mostly done by office employees and for schools many are done by parents when they were taking their children to school and sometimes by the school teacher himself.

\section{Found tools / Items that Have Logos Related to Advertising, Cigarette Promotions and Sponsorships Such as Tablecloths, Tissue holders, Posters, Banners, Stickers, Ashtrays etc.}

Based on the 2011 Ministry of Health Regulation on nonsmoking area guidelines, found tools / items that have logos related to advertising, promotion and sponsorship of cigarettes are like in tablecloths, tissue holders, posters, banners, stickers, ashtrays etc. are a component of the assessment indicator requirements in the application of nosmoking areas in offices, schools and health facilities. Based on the results of the study showed that, the number of observations that met the indicator requirements did not find tools / items that had logos related to advertisements, promotions and sponsors of cigarettes such as tablecloths, tissue holders, posters, banners, stickers from 148 observation places, namely 139 (67\%), ie in the Office of 48 observations (32\%), elementary schools there were $52(35 \%)$, junior high schools met all of them, high school there were $14(9.5 \%)$, public health centres and hospitals filled them all while those who did not meet there were 9 places observations namely in the Office as many as 5 places of observation (3\%), elementary schools there are $3(2 \%)$, high schools there are $1(1 \%)$. From the results of the research found that there are tools / items related to cigarettes there are 9 observation places namely in the office there are 5 namely in (Kesbangpol, Polres, central statistic office, the Office of Women's Empowerment, BMKG), and for SD there are 3 namely in (SDN 62 and SDN 32) for high school namely in high school (MA Darul Ulum). The items / equipment found were ashtrays or trash bins with cigarette logo stickers. The results of other studies show that ad exposure has an effect on adolescent smoking behavior, ${ }^{13}$ commercial advertisement exposure is significantly associated with smoking behavior compared to other brands.

${ }^{14}$ The existence of electronic cigarette advertising can play a role in teenagers' decisions to start using electronic cigarettes and tobacco cigarettes. ${ }^{15}$

\section{Found People Selling Cigarettes}

Based on the 2011 Ministry of Health Regulation on guidelines for non-smoking areas, it was found that people selling cigarettes in offices, schools and health facilities are one of the components of the assessment indicators in the application of no-smoking areas in offices, schools and facilities health. Based on the results of the study found that is found by people who sell cigarettes in the office, school and health facilities, there are 4 observation places and not found as many as 144 observation places, for those found are Office, elementary, junior high, high school as much as $1(0$ $7 \%)$, then for those not available, there are $52(35 \%)$ offices, $54(36 \%)$ elementary schools, 17 (11\%) junior high schools, $14(9.5 \%), 2$ (1) Puskesmas 4\%) and there are 5 hospitals $(3.4 \%)$. From the results of the study found that people sell cigarettes at the observation site, there are 4 observation places, namely in office 1 (in the Operations Office of Babullah UPB, SD 1 (SDN 26), SMP 1 (SMP Muhammadiyah 1), SMA 1 ( MA Darul Ulum) The smoking area is located within the observation environment Crosssectional, longitudinal and experimental studies conducted in the United States have found that there is a relationship between adolescent exposure to cigarette marketing and the initiation of smoking in adolescents. cigarettes to young people including no TV or radio advertisements, bans on the use of cartoons, exposure to advertisements and restrictions on tobacco brand sponsorship for sports events or concerts. ${ }^{16}$

\section{CONCLUSION}

Based on the results of the research conducted, the authors can draw the following conclusions. The low implementation of non-smoking areas in Ternate City, according to the status of the implementation of KTR (No 
[8] Sholeh, M. Asrorun Ni'am. Panduan Anti Merokok untuk Pelajar, Guru, dan Orang Tua, Jakarta: Penerbit Erlangga;2017.

[9] Kota Ternate. Peraturan Daerah Kota Ternate Nomor 4 Tahun 2014 Tentang Ketertiban Umum. (internet). Ternate;2014. (update 2014, cited 2019 March 18). available from: http://www.jdih.setjen.kemendagri.go.id/files/ KOTA_TERNATE_4_2014.docx.

[10] Balai Teknik Kesehatan Lingkungan dan Pengendalian Penyakit Kelas 1 Manado. Laporan Hasil Penilaian Kebijakan Kawasan Tanpa Rokok (KTR) pada Lingkup Sekolah dan SKPD Serta Screening Perilaku Merokok Pada Siswa Sekolah di Kabupaten Tengah Provinsi Maluku Utara Tahun 2018.

[11] Kementrian Kesehatan RI. Pusat Promosi Kesehatan Pedoman Pengembangan Kawasan Tanpa Rokok. Jakarta: kementrian Kesehatan RI;2010. (Update 2011 cited 2018 Dec 28). Available from http://www.depkes.go.id/resources/down load/promosikesehatan/pedoman-ktr.pdf .

[12] Ade Retsy Ambarwati. Penerapan Kawasan Tanpa Rokok Berdasarkan Peraturan Daerah Kota Metro Nomor 4 tahun 2014. Jurnal Ilmiah Hukum Administrasi Negara Fakultas hukum Universitas Lampung. 2017 ; vol 4 (2):1-14. Available from: https://jurnal.fh.unila.ac.id/index.php/han/article/view/897. [13] Muhammad Rachmat, Ridwan Mochtar Taha, Muhammad Syafar. Perilaku merokok Remaja Sekolah menengah Pertama . Kesmas: Jurnal Kesehatan Masyarakat Nasional. 2013;7 (11):502-508.

[14] Hanewinkel R, Isensee B, Sargent JD,Morgenstern M. Cigarrete advertising and adolescent smoking. Am J prev med (serial on the internet). 2010;38(4):359-366 (cited : 2019 sept 30). Available from: http//www.ncbi.nlm.niv.gov/pubmed/20307803

[15] Padon AA, Lochbuehler K, Maloney EK, Cappella JN. A Randomized Trial of the Effect of Youth Appealing E-Cigarette Advertising on Susceptibility to Use ECigarettes Among Youth. Nicotine Tob Res. $2018 \mathrm{Jul}$ 9;20(8): 954-961. doi: 10.1093/ntr/ntx155. PMID : 29106669; PMCID:PMC6037103. Available from: https://www.ncbi.nlm.nih.go v/pmc/articles/PMC6037103/ [16] Biglan, A., Van Ryzin, M. \& Westling, A public health framework for the regulation of marketing .J Public Health Policy. (serial on the internet) 2019 Mar;40(1):66-75. doi: 10.1057/s41271 01801548. Available from: https://www.ncbi.nlm.nih.gov/pubmed/3054 6111

\section{ternate-2018.html}

[6] Hamsa, Widyayanti. Gambaran Kepuasan Pasien Peserta Jamkesmas Terhadap Pelayanan Kesehatan Di Puskesmas Guruapin Kecamatan Kayoa Kabupaten Halmahera Selatan Tahun 2013, (Skripsi), Ternate: Fakultas ilmu Kesehatan Universitas Muhammadiyah Maluku Utara;2013.

[7] Peminatan Epidemiologi. Tugas Analisis Data Epidemiologi (Survei Implementasi Kawasan Tanpa Rokok di Sekolah,Fasilitas Kesehatan dan Kantor), Fakultas Ilmu Kesehatan Universitas Muhammadiyah Maluku Utara ; 2018. 